\title{
Jannal BASIS
}

Vol. 7 No. 2 October 2020

\section{ANALYSIS OF ADDRESS TERMS IN JUSTICE LEAGUE MOVIE}

\author{
Fitri Ventalia ${ }^{1}$ \\ Universitas Putera Batam (UPB), Batam, Indonesia \\ fitri.ventalia3434@gmail.com ${ }^{1}$ \\ Ance Jusmaya ${ }^{2}$ \\ Universitas Putera Batam (UPB), Batam, Indonesia \\ ancejusmaya@upbatam.ac.id ${ }^{2}$
}

\begin{abstract}
The aim of this research was to analyze the type and reason of address terms in WhatsApp group of Putera Batam University Justice League (2017) movie. This research is descriptive qualitative research. The research used observational method non-participatory technique to collect the data. The data was analyzed by applying the theory of Wardaugh (2010). The results found that the type of address terms were 8 data in first name (FN) in Man, Alfred, Diana, Barry, Howard, Silas, Bruce, Victor, 2 data in last name (LN) in Allen, Lane, 2 data in title (T) in Queen, Soldiers, 1 data in title plus last name (TLN) in Ms. Prince, 4 data in pet name (PN) in Aquaman, Batman, Cyborg, Superman and 3 data in kinship term (KT) in Dad, Mother, Child. The research also found the reasons of address term with 12 data in intimacy in Ma, Children, Diana, Man, Victor, Arthur, Barry, Alfred, guys, Bruce, Mom, Superman, 5 data in power differential in Mr. Wilson, Master Wayne, ma'am, insects, Luthor and 3 data in equality in Clark, Steppenwolf and Kal-El. Based on the results, it can be concluded that first name (FN) is the most found type of address term and intimacy is the most in reason of address term. This research is expected to give more understanding about address terms for the readers. The result of this research also expects to improve the ability of students of English Language and Literature Studies Program in using address terms.
\end{abstract}

Keywords: Address Term; Movie; Reason; Type

\section{INTRODUCTION}

People communicate with language to each other. The language is used by people in the society. Language relates to society and studied in sociolinguistics. Holmes (2013) stated that sociolinguistics explains how people talk differently in different social context. Sociolinguistics is useful so that we can understand more about language use and language diversity. The diversity of language users and the social level of language users, language attitudes, and loyalty to language integrity made huge impact in language. The use of language holds important role for the society.
According to Yule (2017), sociolinguistics seeks to explain the correlation between the embodiment of the structure or elements of language with its sociocultural factors.

Society has many varieties of people. The people have their own name. The name can consist of one, two, three or more words. Putri has a friend named Dina. Putri may use the word "Dina" to talk to her like "How are you, Dina?". Dina's complete name is Dina Amelia. Therefore, Putri calls him with his first name. The way to address people is called address term (Wardaugh, 2010). 


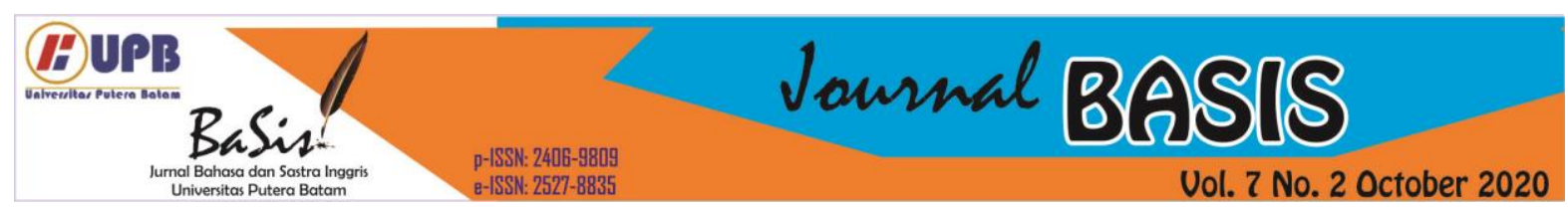

When Putri address Dina with "How are you, Amelia?", it means Putri address her with his last name. Dina in one case greet Putri with "Good morning, mate". Here the word "mate" is also address term. Wardaugh (2010) categorized "mate" as an address term. Putri has a father, he may address his father with "Dad" and his father may also address Putri with "daughter". These are also address term that usually used in family member. The love relationship often uses the word "honey", "darling" and "love" as the way to address. There many ways to address people based on the relationship and situation to the people.

The phenomenon of address terms not only found in the society interaction in real life, but also in movie. This research used movie as the source of data. Movie is moving image footage that tells a story and people watch on a screen or television. The research used Justice League (2017) movie to analyze the address terms.

Justice League is a 2017 American superhero film based on the DC Comics superhero. In the movie, Batman and Wonder Woman recruit The Flash, Aquaman, and Cyborg after the death of Superman to save the world from the catastrophic threat of Steppenwolf and his troops from Parademons. Encouraged by his restored faith in humanity and inspired by Superman's selfless actions, Bruce Wayne sought the help of his newly found ally, Diana Prince, to face an even bigger enemy. Together, Batman and Wonder Woman worked quickly to find and recruit a metahuman team to counter this newly awakened threat. The team defeated Steppenwolf, who, overcome with fear, was attacked by the Parademons themselves. Literature also the mirror of the real phenomenon Arianto \& Simanjuntak (2020). It means that the movie can be correlated with the analysis of socio phenomena.

There were several researches about address terms have done before. Ozcan (2016) focused the research on the use of address terms in spontaneous conversation took place in a no power situation. The main focus of the research was to identify the potential effect of bilingual situations and different cultures. This research investigated the address terms at children school in a reciprocal situation, which will be analyzed regards to the common effect of age, gender and being a monolingual or a bilingual in this moment. The results showed that monolingual children used a wide variety of address term words while bilingual children dwelt on first names more often and the choice of address terms were dominated by politeness, and positive and negative faces.

Nalendra (2018) discussed on the use of address terms uttered in "Love Rosie" movie. The focus of the research was finding type of address term and factor in using the address terms. The theory of address terms was based on Chaika (1982) and Wardhaugh (2006). The research used descriptive qualitative method in the research. The results of the research indicated that there were seven types of address terms which were name, title, combination of title and name, mockery, kinship term and close relationship (intimacy). The three factors of using referred the address terms were occupational hierarchy, gender and degree of intimacy.

The wide variety of words in address terms made address term a unique topic that worth to learn. New words in address terms can be found more in this era such as in society or in media. This research analyzes the types and reason of address terms. There are 


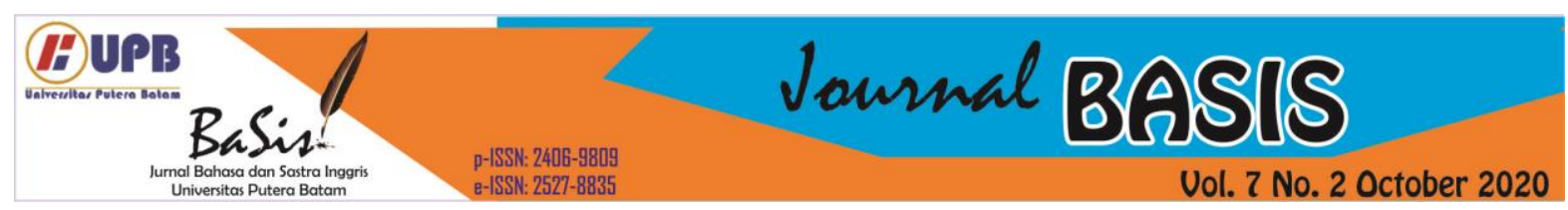

many words in address terms in the source of data that this research used. Therefore the researcher was interested in conducting this research that analyze the use of address term in the Justice League (2017) movie.

\section{ADDRESS TERM}

The way we name or address another is called address terms Wardhaugh (2010). The phenomenon that is influenced by patterns in communication is the use of the term address. People can address another with title, first name, last name, nickname, or by some combination of these words. The choice of a particular type of address term is reflected in the speaker's condition. For example the use of 'I am so sorry honey, can I take you home?' from someone she doesn't know who the person, is someone would not expect to get. It can be concluded that the speaker and receiver do not know each other and do not have a close relationship. Mrs Betty would expect being called Mrs from her student. A father would expect being called "Daddy" from his son, Betty from his sister, Honey from his girlfriend and Doctor from a doctor who check his health at the hospital. There many combinations of addressing available to address someone, Prof Mark, Betty Jane, Violet, Gordon, Keith, Doc, Mr, mate, and many other.

Based on Wardhaugh (2010), there are six types of the addressing terms in use of people. The types of address terms that can be used by people are, the types of address terms are first name $(\mathrm{FN})$, title and last name (TLN), title only $(\mathrm{T})$, last name $(\mathrm{LN})$, pet name $(\mathrm{PN})$ and kinship term (KT). In address terms, the use of first name (FN) the speaker uses the first name to address, such as Putri or Dina. Beside that type, there are also address term like "Man", "Buddy", "boy", or "Mate" as the generic first name, like in 'How is it going, Buddy?' or 'Hi, Mate, I am good.' (Wardhaugh, 2010). Last name (LN) address term, the speaker uses the last name to address. Such as in Putri in "Putri Melina". The address term of title ( $\mathrm{T})$, means that a person addresses someone only by his/her title, such as, "Doctor", "Professor". The other title such as "Mrs", "Miss", "Sir" or "Ma'am" is generalized title. The combination of title and last name formed title and last name (TLN) such as in "Mrs Bella" who worked as a teacherPet name (PN) is the special name someone uses for someone to show love or affection or to name specially.

It could be "Honey", "Babe", "Kitty". The last is kinship term (KT). It is the name of family member position relationship like "Dad", "Mother", "Mom", "Aunty", "Grandpa" and "nan".

The address term also have the reason of using address term. The address term is influenced by patterns in communication. The choice of a particular type of address term is reflected in the speaker's condition. According to Wardaugh (2010), the reason of address term is intimacy, power differential and equality. The reason for intimacy is, he can see the intimate relationship between the speaker and the addresser. Addressing with the title is the most intimate of the address terms. The title usually designates rank or occupation. It can be concluded that Prof. Putri is more intimate than just a prof. Acknowledge that the actual intimacy of other people's names is recognized and can be pronounced. The use of a first name indicates intimacy or at least a tendency for intimacy. Using the name of a pet shows greater intimacy. When someone uses only the first name in speaking, people may feel that the person is trying 


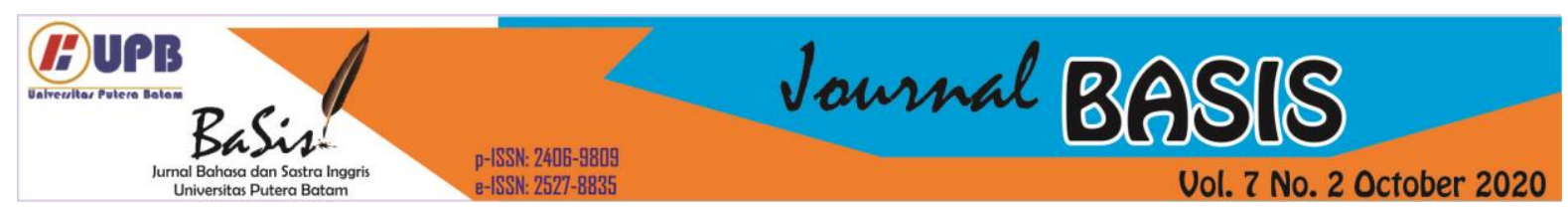

to show intimacy. The reason of power differential shows asymmetric level of power between the speaker and the hearer. It shows that the use of asymmetric title, last name, and first name (TLN / FN) indicates inequality in power, that the shared TLN shows inequality and unfamiliarity. The transition from reciprocal TLN to $\mathrm{FN}$ is also usually initiated by members of stronger relationships. The reason of equality indicates the presence of the same level of power between the speaker and the hearer. First name indicates equality in conversation.

The phenomenon of address term is widely analyzed. Tauchid (2018) aimed to analyze how address terms in The Secret Island novel. In conducting the research, the researcher used descriptive qualitative method. The research found, the characters in the novel used three types of address terms, there were first name (FN), title plus last name (TLN), and kinship terms (KT). Address terms were used based on the relationship between the character and can be described as below: first name (FN) was used when the relationship was very close or intimate, such as close friend, siblings, girlfriend; title plus last name (TLN) was used when the relationship was not so very close and people were older than them, such as aunt Harry, uncle Jack, etc; kinship terms (KT) was used when the relationship was family member, such as daddy, mommy, mother, father, , uncle, aunty.

Rahmadani (2018) aimed to find type and function of address terms uttered by student in IPMK-SB "Kampar Students Studying in Padang". This research used theory by Esmae'li (2011) and Wardhaugh (2006) about address terms theory. This research used descriptive qualitative method. The result found that among seven types of address term based on Wardhaugh (2006), it was found only four types of address term uttered by IPMK-SB. They were kinship terms, pet name, special nickname and title only. The next finding, the research found five functions of address terms based on Wardhaugh (2006) and Esmae'li (2011) theory. There were show intimacy, show politeness, attract people attention, reflect identity and show power differential.

The phenomenon of address term is widely analyzed in many research. Prasetyoaji (2020) purpose of this study was to determine the depiction pattern of social actors with the social actor approach, find evidence of linguistic patterns using transitivity, explain the depiction of social actors based on the patterns found, and compare the results. with the context and genre of the biography. This research produces the following results: various patterns of representation of social actors are used by the writer to convey their intentions and stances regarding social actors, the processes contained in the text are identified using transitivity, thus providing evidence of language, patterns of representation. the most common are: activation, passivation (conquest and gain), determination, nomination, functionalization, and instrumentalization. These patterns can be concluded as mandatory patterns in the biographical text, and the analyzed text is relevant to the quality of the biographical text.

Simanjuntak (2020) discusses the application of modern anthropolinguistics (competence, performance, indexicality, and participation) in the Toba Umpasa Batak culture. Linguistic anthropology studies structure and relationships through kinship terms, color concepts, parenting, 


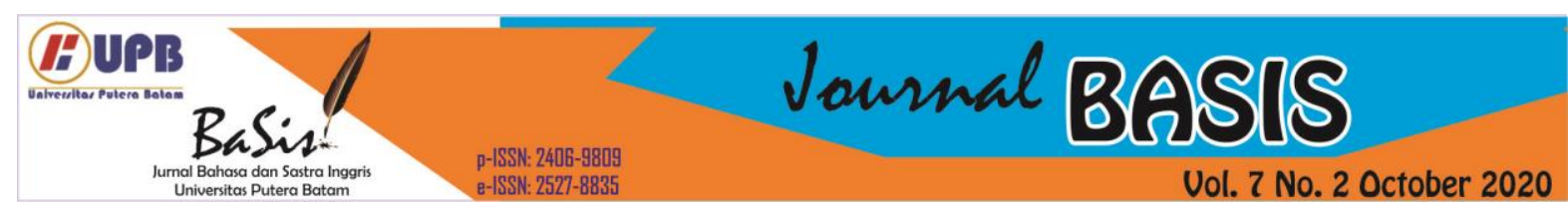

or the study of how members of the community communicate with each other in certain situations such as us in traditional ceremonies, then relate them to cultural concepts. Umpasa contains poetic values, containing the philosophy of life, namely 'Hagabeon' (happiness), 'Hamoraon' (wealth), 'Hasangapon' (respected), and 'Saur Matua' (long life and prosperity). The writer applies this modern anthropolinguistic theory to find out how the knowledge of a language is controlled by the speaker of a language and the use of language which is proven in actual communication as a reflection of the speaker's mind about the signs it has. existential relationship with reference and speaker involvement to produce an acceptable form of speech in the Toba Batak culture 'umpasa'.

Pauletto, Aronsson and Galeano (2016) with the title "Endearment and Address Terms in Family Life: Children and Parents' Request in Italian and Swedish Dinnertime Interaction". This study is focused on the use of the terms affection and affective in asking questions in family interactions as a social action. The results showed that the term affection was mostly used by parents, not children. Children show their affective attitude in nonverbal and non-vocal arrangements. In addition, parents use affectionate terms, nicknames, and small words, as lexical tools involving intimate bonding. Moreover, children's requests that are intended as immediate action against food-related activities and requests from parents are often considered repressive actions, influenced by children's behavior.

Ethelb (2015) with a research entitled "Using Address Terms in Showing Courtesy with Reference to Translation from Arabic to English". Researchers investigated the translation of Arabic address terms into English. The politeness theory from Brown and Levinson (1987) is used to determine whether the translation of the greeting terms in the target language still holds politeness or not. Researchers took data from a novel Madiq Alley. The analysis shows the use of nicknames and how politeness strategies are applied differently to show respect. The results indicate that some of the address terms appear burdensome or problematic and tend to be sacrificed as hypothesized in the translation process.

\section{RESEARCH METHOD}

Research designs have two types of designs which are; quantitative research and qualitative research. Quantitative research is a method of research that uses data in number and percentage to find the data. Qualitative research is a method of research which has data in comprehension because it cannot be measured by number and percentage. This research is a descriptive qualitative research because the data taken is in the form of words, phrases and sentences that needs to be in comprehension.

Address term is object of this. The theory used in this research is from Wardhaugh (2010). The theory of address term consists of the type and reason of address term. The theory is used to analyze address terms in the Justice League (2017) movie.

This research applied a nonparticipatory observation method proposed by Sudaryanto (2015) in collect the data. Observation method is a method to collect data by observing the research through the context around the data. The technique of non participatory is type observation method in collecting the data without having to involve to interact with the speakesr. The technique of non participatory was applied due to 


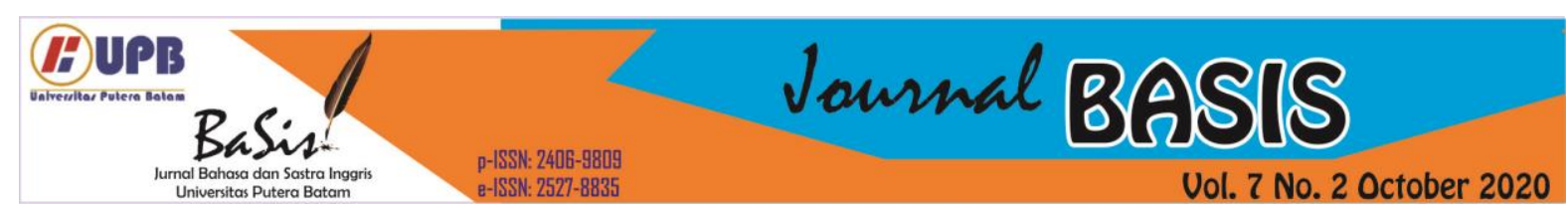

no need of interaction with the speaker in the movie.

The method applied to analyze the data in this research is categorization. Categorization is an intuitive process that is systematic and reasoned based on the research goals, orientation and research's knowledge (Sudaryanto, 2015). The researcher started by understanding the theory, then to find data of the address term found in the utterance. Then, analyzing the data and search the type and reason according to the theory.

The method for presenting research results applied to this research is formal method. The informal method uses ordinary words to explain the research result (Sudaryanto, 2015). The informal method was applied because data of analysis in the results are have the form of word and phrase without number and percentage.

\section{RESULT AND DISCUSSION}

After analyzing the address terms in the Justice League (2017) movie, the researcher found some results. The results consist of the types of address terms and reasons of address terms according to the theory proposed by Wardhaugh (2010).

\subsection{Type of Address Terms A. First Name (FN)}

\section{Datum 1}

Henry : I want you to listen to me, Barry, because I mean this.

Barry was visiting his father in a jail. They were talking though the phone. His father suggested Barry to not to visit him again in jail because it was too suspicious for the police. The conversation above shows the address term "Barry". His father addressed Barry with "Barry". It is the first name from Barry Allen. His father used the address term of first name (FN). Therefore, "Barry" is an address term with the type of first name $(\mathrm{FN})$.

\section{Datum 2}

Bruce seeing this?

: Alfred, are you

Bruce and Alfred were investigating a teenager who seemed like a superhero. They were looking at the monitor. Bruce found something suspicious and called Alfred. Alfred's real name is Alfred Pennyworth. The conversation above shows the address term "Alfred". Bruce addressed him with "Alfred". Therefore, the address term of first name $(\mathrm{FN})$ is used in the utterance. Therefore, "Alfred" is an address term with the type of first name (FN).

\section{Datum 3 \\ Bruce : What about, uh, Diana?}

Bruce was talking to Arthur about the team they built. They were planning to recruit Diana into the team to fight Steppenwolf. The conversation above shows the address term "Diana". Bruce used to the word "Diana" to address Diana. It is the front name of Diana Prince. Bruce applied the first name (FN) address term to Diana. Therefore, "Diana" is an address term with the type of first name (FN).

\section{Datum 4}

Thief : Please! Please, man. Please!

A thief was doing his crime to a woman. Then Cyborg came to stop the crime. Cyborg threatened the thief by doing hurt to him. The thief did not recognize cyborg and just address him "man". The conversation above shows the address term "man". The word "man" is classified as the first name (FN) address terms. It is in term of 


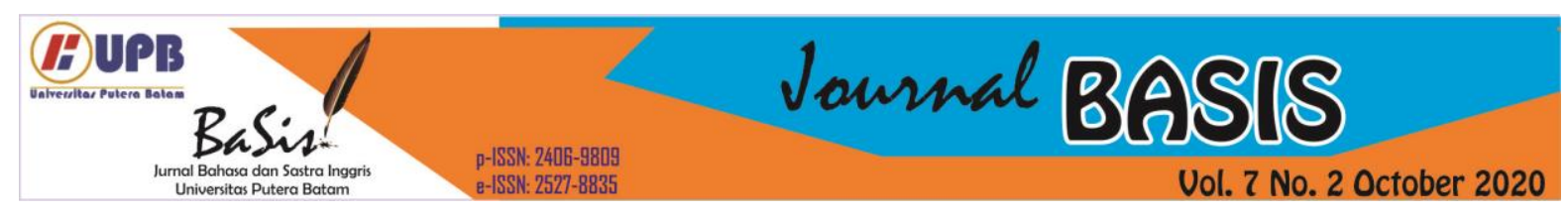

generalized first name. Therefore, "man" is an address term with the type of first name $(\mathrm{FN})$.

\section{B. Last Name (LN)}

\section{Datum 5}

Bruce : Let's go, Allen.

There was a fight against the enemy. Barry fell into the ground from the fight. Bruce came to help him to stand up. The conversation above shows the address term "Allen". Bruce addressed Barry with "Allen". It is the last name from "Barry Allen". Therefore, Bruce applied the last name (LN) address term to Barry. Therefore, "Allen" is an address term with the type of last name (LN).

\section{Datum 6}

\section{Clark : Hey, Lane.}

Clark was just alive again from death by the help from his team. He was shocked and just flew to meet his mother and also met Lois there. The conversation above shows the address term "Lane". Clark addressed her with his last name "Lane". The address term of last name (LN) was used by Clark to address Lois Lane. Therefore, "Lane" is an address term with the type of last name (LN).

\section{Title (T)}

\section{Datum 7}

Soldier: No, Queen.

The kingdom of Amazon was waiting for the arrival of Steppenwolf. Queen Hippolyta asked about the situation to her soldier. The conversation above shows the address term "Queen". The soldier addressed Hippolyta with "Queen". It is the title position of Hippolyta as the queen of the Amazon kingdom. The soldier used the address term of Title (T). Therefore, "Queen" is

an address term with the type of Title (T).

\section{Datum 8}

Steppenwolf : Yes, soldiers! Fight on!

Steppenwolf arrived at his place on earth and built the defence. $\mathrm{He}$ commanded his soldier to go and fight the enemy. The conversation above shows the address term "soldier". Steppenwolf addressed his soldier with "soldier" as it is the position of the job of the them as the soldier of Steppenwolf. Therefore, the address term of Title (T) is used in the utterance. Therefore, "soldier" is an address term with the type of Title (T).

\section{Title plus Last Name (TLN) Datum 9}

Alfred : Looks like you have a date, Ms. Prince.

Diana had an invitation from Victor to meet him secretly. Victor wanted to make sure that the person did not hurt him. The conversation above shows the address term "Ms. Prince". Alfred addressed Diana with "Ms. Prince". "Ms" is a generalized title for a woman still unmarried and "Prince" is the last name from "Diana Prince". Alfred applied the title plus last name (TLN) address term. "Mserefore, Prince" is an address term with the type of title plus last name (TLN).

\section{E. Pet Name (PN)}

Datum 10

Bruce : Also known as protector of the oceans, the Aquaman.

Bruce tried to find the Aquaman who was still unknown. He finally found him in a village and confronted him. The conversation above shows the address term "Aquaman". Bruce called him "Aquaman". "Aquaman" is the special 


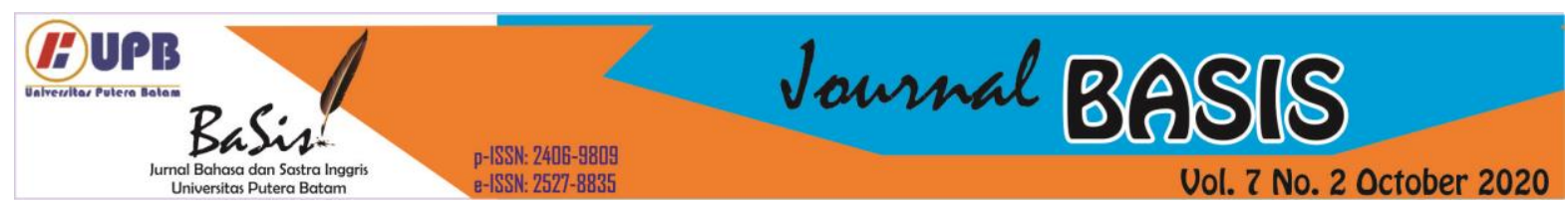

name Arthur had as he is a superhero from the sea. Bruce used the pet name (PN) address term. Therefore, "Aquaman" is an address term with the type of pet name (PN).

\section{Datum 11}

Arthur : Don't count on it, Batman.

Bruce met Arthur for the first time. They had a little heat on their meeting. The conversation above shows the address term "Batman". Arthur called him "Batman". The word "Batman" is classified as the pet name (PN) as it is the hero name from Bruce Wayne as he dressed in Bat suit and had ability and power like Bat. Therefore, "Batman" is an address term with the type of pet name (PN).

\section{Datum 12}

Bruce : Did you find the Cyborg?

Bruce tried to find Victor with Diana. They worked together to find him. The conversation above shows the address term "Cyborg". Bruce addressed Victor with "Cyborg". It is the hero name given by people to Victor as he had the ability like super robot with advanced weapon and flight. The address term of pet name (PN) was used by Bruce to address Victor. Therefore, "Cyborg" is an address term with the type of pet name (PN).

\section{F. Kinship Term (KT)}

Datum 13

Victor : Dad, that's not true.

Victor found his father, Silas, was being detained by Steppenwolf. Steppenwolf tried to manipulate Victor's father's mind. The conversation above shows the address term "father". Victor addressed Silas with "father". It is because Silas Stone is Victor's father. Victor used the address term of kinship term (KT) to address his father. Therefore, "father" is an address term with the type of Kinship Term (KT).

\section{Datum 14}

Steppenwolf : I see, Mother.

Steppenwolf met his mother at his ship. His mother showed the way to find the box to Steppenwolf. The conversation above shows the address term "mother". Steppenwolf addressed his mother with "mother". Steppenwolf had a mother with a shape of light. Therefore, the address term of kinship term (KT) is used by Steppenwolf. Therefore, "mother" is an address term with the type of Kinship Term (KT).

\section{Datum 15}

Steppenwolf : Child, my ax is still slick with the blood of your sisters.

Steppenwolf arrived at the Amazon kingdom to take his box. He confronted the people of amazon. The conversation above shows the address term "Child". Steppenwolf used the word "Child" to address the people of Amazon. It is because he used to come there hundred years ago and he felt that he was older than all the present people. Steppenwolf applied the kinship term (KT) address term to Amazon people. Therefore, "Child" is an address term with the type of Kinship Term (KT).

\subsection{Reason of Address Terms}

\section{A. Intimacy}

\section{Datum 1}

Clark : I'm really me, Ma.

Clark was just reborn from death. His friend helped him to be alive again. Clark just flew to his mother house after he reborned. His mother did not believe Clark was alive. Clark addressed his mother with "Ma". It is short form of "Mother" which is kinship term. Clark 


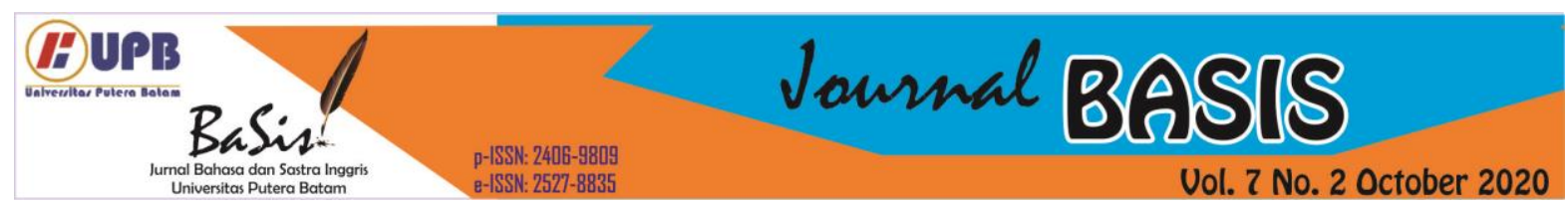

used "Ma" because he was so close with his mother. His mother took care and loved him since he was child. The whole movie showed how intimate the relationship between them. This context indicates that Clark and his mother had intimacy as a mother and son.

\section{Datum 2}

Diana : Children. I work with children

The justice team just defeated Steppenwolf. Superman and Cyborg just got thrown far away because of an explosive. They laugh together. Diana addressed them with kinship term "child". It is because how close they were through the entire movie as a team and made Diana was able to call children because they acted like children. This context indicates that Diana and friends had intimacy as a friend.

\section{Datum 3}

Victor : Diana, there's no time.

Victor and the team planned to fight Steppenwolf. They were holding the box of magic portal to prevent it to open. Victor called first name "Diana" to address. They were friend as a team in the story. It shows the intimate relationship as a friend between them as the team to fight the enemy. This context indicates that Diana and Victor had intimacy as a friend.

\section{Datum 4}

Victor : Man, my toes hurt!

Victor just bumped into a building while fighting the enemy while flying with Arthur. Victor said "Man" to Arthur as the first name. It is because they were friends and at the same team that recruited by Bruce to fight Steppenwolf. From the beginning of the movie they helped each other to be close friends.
This context indicates that Arthur and Victor had intimacy as a friend.

\section{Datum 5}

Diana : Just think happy thoughts, Victor.

Victor was holding the mother box from opening. It prevents the earth from destroying from Steppenwolf army. Diana addressed with the first name "Victor". Diana and Victor were friends in the justice team. Diana recruited Victor and they became friends since then helping the team to win. This context indicates that Diana and Victor had intimacy as a friend.

\section{Datum 6}

Bruce : Arthur, we need to restrain him.

Arthur and Bruce and the rest of the team were fighting Steppenwolf. At one time they hold Steppenwolf and need to be restrained. Bruce asked helped to Arthur by addressing his first name "Arthur". The reason is because they were team mates and also friends. The relationship showed their close intimate as a friend. This context indicates that Bruce and Arthur had intimacy as a friend.

\section{Datum 7}

Bruce : Barry, go find Alfred in the pantry.

Bruce asked Barry to find Alfred when they were in Bruce's home. Bruce uttered Barry's first name "Barry". Bruce recruited Barry to his team. They became friend and teammate to work together to recruit another hero and fight against Steppenwolf. This context indicates that Bruce and Barry had intimacy as a friend.

\section{Datum 8}




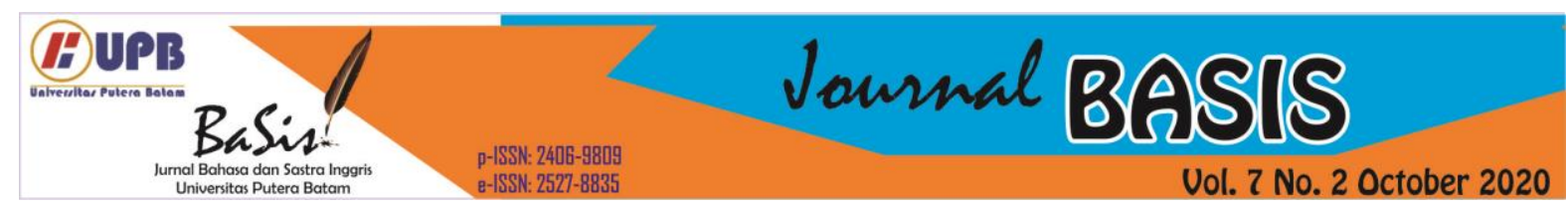

Bruce : Alfred, I need the nightcrawler.

There was a fight between the team with Steppenwolf. Bruce asked Alfred to send his vehicle to his position to help him. Alfred is Bruce's assistant for a long time. They were really close and already like family. Alfred had been working for Bruce for so many years. This context indicates that Bruce and Alfred had intimacy as a friend.

\section{Datum 9}

Arthur : Sorry, guys. I didn't bring a sword.

Arthur was throwing his spear to kill enemy to help Bruce. Then he mentioned that he did not have sword to be the weapon. Arthur addressed his friend "guys" as the generalized first name. Arthur talked to his friend because they were also the teammates. They worked together that built their relationship as friends in the movie. This context indicates that Arthur and Clark had intimacy as a friend.

\section{B. Power Differential}

\section{Datum 10}

Lex : We have to level the playing field, Mr. Wilson.

Lex invited Wade Wilson to his ship in the ocean. Wade came to him by a boat. Lex greeted him with title plus last name "Mr. Wilson". It is because there was different power between them. Wade Wilson is a superhero while Lex just a normal human being. Wade was also the guest that Lex need. This context shows that Lex and Wade Wilson had power differential. Wade Wilson was the inferior and Lex was the superior.

\section{Datum 11}

Alfred : No, Master Wayne.
Bruce asked the condition of his weapon to Alfred. Alfred was Bruce's assistant. He worked to manage the need of Bruce. Alfred addresses with title plus last name "Master Wayne". It is because Alfred was the one who worked for Bruce Wayne while Bruce was the boss. This context shows that Alfred and Bruce had power differential. Alfred was the inferior and Bruce was the superior.

\section{Datum 12}

Clark : Yes, ma'am.

Clark met his mother for the first time after his death. He was reborn by the help of his friends. His mother wanna make sure that it was the real Clark. Clark used the kinship term "ma'am" to answer. Here shows the different power at the level of family. Clark is the children while his mother as the mother. This context shows that Clark and his mother had power differential. Clark was the inferior and his mother was the superior.

\section{Datum 13}

Nelson : Come on, Luthor. Let's go.

Luthor was the criminal who got put in jail. He was being asked to get out of the cell by Nelson the security. Nelson was able to address him with the last name "Luthor" because there was a different power. Nelson as the security of the cell and Luthor as the criminal. This context shows that Nelson and Luthor had power differential. Luthor was the inferior and Nelson was the superior.

\section{Equality}

Datum 14

Bruce : And the team needs Clark.

Bruce explained the need to get Clark back $t$ life to his teammates. Bruce address with first name "Clark". It is 


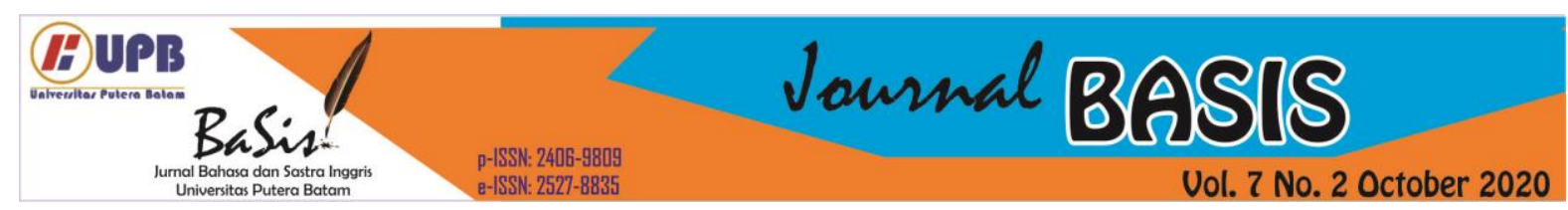

because Bruce and Clark were the same position as superhero. Bruce as the Batman and Clark as the Superman. They were both the main character in the movie. This context indicates that Bruce and Clark had equality as heroes.

\section{Datum 15}

Diana : Steppenwolf, he took the Mother Box from Atlantis.

Diana was explaining the journey of mother box from Steppenwolf. It shows how the box was taken. Diana addresses with first name "Steppenwolf". It is because they have the same position as the enemy and the ally. They were same as hero who have their own power. This context indicates that Diana and Steppenwolf had equality as enemy.

\section{CONCLUSION}

The research concludes based on the research finding. This research analyzed the address term in the Justice League (2017) movie. The address term have the type and reason of using address terms based on Wardhaugh (2010). The research found type of address term with 8 data in first name (FN), 2 data in last name (LN), 2 data in title (T), 1 data in title plus last name (TLN), 4 data in pet name (PN) and 3 data in kinship term (KT). The research also found the reasons of address term with 12 data in intimacy, 5 data in power differential and 3 data in equality. The result of this research, the research found that influences from the diversity and environment made a big impact on the use of address term. The situation of conversation in utterance depends on the subject, position and relationship in the utterance.

\section{REFERENCES}

Arianto, T., \& Simanjuntak, D. S. (2020). Representation of ecocriticism in the folklore of Mak Ungkai spirit. Studies in English Language and Education, 7(2), 576-591. http://erepository.unsyiah.ac.id/SiELE/arti cle/view/16822

Ethelb, H. (2015). Using address terms in showing politeness with reference to their translation from Arabic into English. International Journal of Comparative Literature and Translation Studies, 3(3), 27-37. https://doi.org/10.7575/aiac.ijclts.v.3 n.3p.27

Holmes, J. (2013). An introduction to sociolinguistic ( $4^{\text {th }}$ ed.). New York, NY: Routledge.

Nalendra, A., Wulandari, A., Khoirunnada, M., Susanti, I., \& Putra, O. (2018). An analysis of addressing term in used in the Love Rosie movie. Progressive Journal, 13(2), 71-78. $\quad$ DOI: https://ejournal.nusamandiri.ac.id/in dex.php/ progressive/article/view/529

Ozcan, F., H. (2016). Choice of address terms in conversational setting. International Journal of Human Sciences, 13(1), 982-1002. DOI: https://jhumansciences.com/ojs/index.php/IJ HS/article/view/3489

Pauletto, F., Aronsson, K., \& Galeano, G. (2017). Endearment and address terms in family life: Children's and parents' requests in Italian and Swedish dinnertime interaction. Journal of Pragmatics, 109(3), 8294. https://doi.org/10.1016/j.pragma.201 6.12.014 


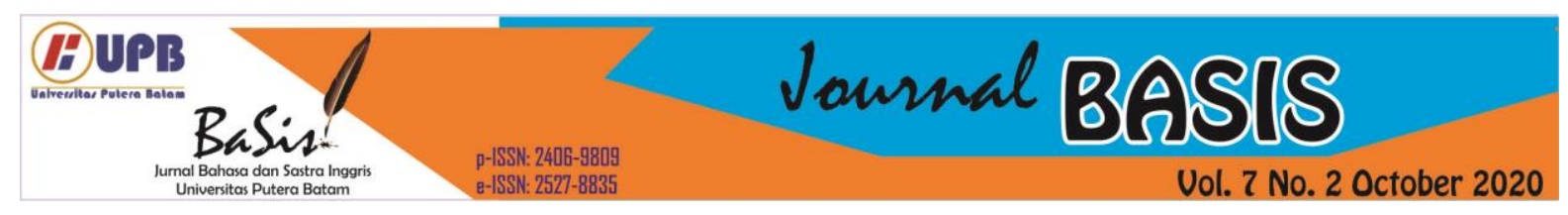

Prasetyoaji, A. (2020). Transivity on elon musk's online biography:a social actors discourse analysis. Journal Basis, 7(1), 13-24. DOI: https://doi.org/10.33884/basisu pb.v7i1.1673

Rahmadani1 \& Wahyuni, D. (2018). Types and functions of address terms used by IPMK-SB "Kampar Students Studying in Padang". EJournal of English Language \& Literature, $\quad 7(1), \quad$ 132-142. DOI: http://ejournal.unp.ac.id/index. php/jell

Simanjuntak, D. (2020). Penerapan teori antropolinguistik modern (competence, performance, indexicality, \& partisipation) dalam umpasa budaya batak toba. Journal Basis, 2(2), 71-78.

DOI:

http://ejournal.upbatam.ac.id/index. php/basis/article/view/407

Sudaryanto (2015). Metode dan aneka teknik analisis bahasa. Yogyakarta, Indonesia: Sanata Dharma University Press.

Tauchid, A. (2018). In search of address terms in novel. Loquen: English Studies Journal, 11(2), 15-28. DOI: http://dx.doi.org/10.32678/loq uen.v11i02.1278

Wardaugh, R. (2010). An introduction to sociolinguistics. England: Wiley Blackwell.

Yule, G. (2017). The study of language. Cambridge, United Kingdom: Cambridge University Press.

Arianto, T., \& Simanjuntak, D. S. (2020). Representation of

ecocriticism in the folklore of Mak Ungkai spirit. Studies in English Language and Education, 7(2), 576-591. http://erepository.unsyiah.ac.id/SiELE/arti cle/view/16822

Wardaugh, R., \& Fuller, J. M. (2015). An Introduction to Sociolinguistics. In B. B. Ltd (Ed.), Journal of Chemical Information and Modeling (Seventh Ed). Wiley Blackwell. https://doi.org/10.1017/CBO978110 7415324.004 